\title{
Mengurangi Nyeri Persalinan dengan Teknik Birthing Ball
}

\author{
Ayu Irawati ${ }^{*}$, Susianti ${ }^{1}$, Iranita Haryono ${ }^{2}$ \\ ${ }^{1}$ STIKES Mega Buana Palopo \\ ${ }^{2}$ Universitas Muhammadiyah Sidenreng Rappang \\ *Email korespondensi: Irawati01ayu@gmail.com
}

\section{$\begin{array}{ll}\text { Article Info } & \text { ABSTRACT }\end{array}$}

Article history:

Submitted: 2019-10-31

Accepted: 2019-12-23

Published: 2019-12-30

Keywords:

Birthing ball; Labor pain; First stage active phase

Pain during labor is caused by the first stage of labor in which contractions cause dilation and thinning of the cervix and uterine ischemia due to contraction of the myometrial arteries. These contractions cause the opening of the cervix to begin labor. Various attempts are made to reduce labor pain, both pharmacologically and non-pharmacological. The non-pharmacological method applied is a distraction with birth balls. The research aims to prove the effectiveness of the use of birthing ball on the reduction of labor pain in the first stage of labor in the active phase. This study used an experimental research design with a pretest-posttest control group design. The research sample was 20 maternity mothers at the Lompoe Health Center, who received treatment and 20 people as control samples. It applied the purposive sampling technique. The instrument of observation was the pain scale using the Faces Pain Rating Scale. Data processing using the Wilcoxon-test to determine the effect of the treatment given. Based on the results of the bivariate analysis showed that the $p$-value is $<0,001$. In conclusion, there is an influence of using the birthing ball to reduce the level of pain in the first stage of labor in the active mother.

\section{ABSTRAK}

Kata kunci:

Birthing ball; Nyeri persalinan; Kala I fase aktif
Rasa nyeri selama persalinan disebabkan oleh kala I persalinan yang kontraksinya menyebabkan dilatasi dan penipisan serviks serta iskemia rahim akibat kontraksi arteri miometrium. Kontraksi ini menyebabkan adanya pembukaan serviks untuk memulai terjadi persalinan. Berbagai upaya dilakukan untuk menurunkan nyeri persalinan baik secara farmakologi maupun nonfarmakologi. Metode nonfarmakologi yang dilakukan ialah distraksi dengan birthball. Penelitian bertujuan untuk mengetahui pengaruh penggunaan birthing ball terhadap pengurangan nyeri persalinan pada ibu bersalin kala I fase aktif. Penelitian ini menggunakan desain penelitian Experimental dengan rancangan Pretest-Posttest Control Group Design. Sampel penelitian adalah ibu bersalin di Puskesmas Lompoe sebanyak 20 orang yang mendapat perlakuan dan 20 orang sebagai sampel kontrol. Teknik pengambilan sampel dengan Purposive Sampling. Instrumen penelitian observasi skala nyeri dengan Faces Pain Rating Scale. Pengolahan data menggunakan uji Wilcoxon-test untuk mengetahui efek dari perlakuan yang diberikan. Berdasarkan hasil analisis bivariat menunjukan bahwa nilai $p$ adalah $<0,001$. Dapat disimpulkan bahwa ada pengaruh penggunaan birthing ball terhadap penurunan tingkat nyeri pada Ibu bersalin kala I fase aktif. 


\section{PENDAHULUAN}

Menurut data $\mathrm{WHO}$, sebanyak $99 \%$ kematian ibu akibat masalah persalinan atau kelahiran. Angka kematian yang tinggi umumnya disebabkan kurangnya pengetahuan tentang sebab dan penanggulangan komplikasi kehamilan, persalinan dan nifas. ${ }^{1}$ Dari hasil Survei SDKI menunjukan AKI dan AKB di Indonesia belum mencapai target yang diharapkan oleh MGD's tahun 2015 AKI akan turun menjadi 102 /100.000 KH dan AKB 23/1000 KH. ${ }^{2}$ Kota Parepare merupakan salah satu kota di provensi Sulawesi Selatan yang menjadi salah satu kota penyumbang angka kematian ibu dan bayi. Menurut laporan Dinas Kesehatan kota Parepare tahun 2016 jumlah kasus kematian Ibu sebanyak lima orang. ${ }^{3}$

Proses persalinan identik dengan rasa nyeri yang akan dijalani. Secara fisiologis nyeri terjadi ketika otot-otot rahim berkontraksi sebagai upaya membuka servik dan mendorong kepala bayi kearah panggul. Nyeri pada persalinan kala I merupakan proses fisiologis yang disebabkan oleh proses dilatasi serviks, hipoksia otot uterus saat kontraksi, iskemia korpus uteri dan peregangan segmen bawah rahim dan kompresi saraf diservik. ${ }^{4}$

Berbagai upaya dilakukan untuk menurunkan nyeri pada persalinan, baik secara farmakologi maupun nonfarmakologi. Beberapa tipe penatalaksanaan dalam mengatasi nyeri dengan metode nonfarmakologis, yang disukai oleh ibu melahirkan untuk mengatasi nyeri adalah metode distraksi dengan birth ball yang dapat menurunkan nyeri fisiologis. ${ }^{5}$

Berdasarkan survei pendahuluan yang telah dilakukan di Puskesmas Lompoe, pada bulan april dari 15 orang ibu bersalin, peneliti telah melakukan observasi pada 10 responden yang diambil secara acak, didapatkan bahwa 7 dari 10 ibu bersalin mengalami nyeri yang tak tertahankan saat persalinan kala I fase aktif, dan 3 lainnya mengalami sedikit nyeri pada kala I fase aktif. Karena masih tingginya kejadian nyeri persalinan kala I, di Puskesmas Lompoe maka dengan ini penulis akan melakukan intervensi menggunakan birthing ball untuk mengetahui pengaruh penggunaan birthing ball terhadap penurunan nyeri persalinan pada ibu bersalin kala I fase aktif dengan tujuan untuk menurunkan angka kesakitan pada saat persalinan.

Berdasarkan data tersebut peneliti tertarik ingin membuktikan penelitian tentang penggunaan birthing ball dengan tujuan untuk mengetahui pengaruh teknik birthing ball terhadap pengurangan nyeri persalinan pada ibu bersalin kala I fase aktif di Puskesmas Lompoe.

\section{METODE PENELITIAN}

Dalam penelitian ini menggunakan desain penelitian experimental dengan rancangan pretest-posttest control group design. Pada penelitian ini responden terbagi menjadi dua kelompok yaitu kelompok perlakuan dan kelompok kontrol. Lokasi penelitian ini dilakukan di Puskesmas Lompoe. Waktu Penelitian dilaksanakan pada bulan Mei sampai Agustus Tahun 2019. Populasi dalam penelitian ini adalah seluruh ibu bersalin normal kala I fase aktif yang bersalin di Puskesmas Lompoe yang memenuhi kriteria inklusi: Ibu bersalin normal, dengan usia kehamilan $\geq 37$ minggu, janin tunggal hidup, presentasi kepala, tidak dilakukan induksi persalinan, ibu bersalin kala I fase aktif (pembukaan 4-6 cm), his adekuat (kontraksi uterus $>3$ kali dalam 10 menit dengan lama kontraksi $>40$ detik), persalinannya didampingi oleh suami atau keluarga terdekat, tidak menggunakan metode farmakologis dan non farmakologis untuk mengurangi nyeri persalinan, dan ibu kooperatif. Sampel dalam penelitian ini sebanyak 20 ibu bersalin pada kelompok perlakuan dan 20 ibu bersalin pada kelompok 
kontrol. Teknik pengambilan sampel dalam penelitian ini dilakukan secara tidak acak dengan tehnik purposive sampling yaitu pemilihan sampel dengan menetapkan subyek yang memenuhi kriteria penelitian dimasukkan dalam penelitian sampai kurun waktu tertentu, sehingga jumlah responden dapat terpenuhi.

Instrument dalam penelitian ini menggunakan skala nyeri Faces Pain Rating Scale (FPRS) dengan cara obsevasi dan wawancara, serta lembar partograf. Pengumpulan data dilakukan pada kelompok perlakuan dengan mengobservasi ibu bersalin kala I fase aktif dengan cara memberikan pretest (pengamatan awal) terlebih dahulu sebelum diberikan perlakuan, setelah itu diberikan birthing Ball, kemudian dilakukan posttest (pengamatan akhir) dengan lembar observasi yang berisi skala penilaian skala nyeri dengan observasi FPRS. Analisis data menggunakan Wilcoxontest. Analisis Univariat yang diperoleh dari hasil pengumpulan data disajikan dalam bentuk table distribusi frekuensi dan presentase. Analisa bivariat digunakan untuk mengetahui pengaruh teknik birth ball terhadap pengurangan nyeri persalinan di Puskesmas Lompoe. Dalam menganalisa data secara bivarit penyajian data dilakukan dengan menggunakan uji statistic Wilcoxon-test untuk mengetahui efek dari perlakuan yang diberikan.

\section{HASIL PENELITIAN}

Penelitian dilakukan selama tiga bulan yaitu pada bulan Mei sampai Agustus 2019 di Puskesmas Lompoe. Sampel diambil secara purposive sampling sehingga didapatkan sampel sebanyak 40 ibu bersalin yang dibagi menjadi 2 kelompok, yaitu 20 responden ibu bersalin kelompok perlakuan yang diberikan terapi birthing ball, dan untuk kelompok Kontrol sebanyak 20 responden ibu bersalin tanpa perlakuan, tetapi diajarakan relaksasi napas dalam. Berikut disajikan hasil penelitian secara keseluruhan.

Tabel 1. Distribusi Frekuensi Responden Berdasarkan Karakteristik

\begin{tabular}{|c|c|c|c|c|c|c|}
\hline \multirow[t]{2}{*}{ Karakteristik } & \multicolumn{2}{|c|}{ Perlakuan } & \multicolumn{2}{|c|}{ Kontrol } & \multicolumn{2}{|c|}{ Total } \\
\hline & $\mathrm{n}=\mathbf{2 0}$ & $\%$ & $n=20$ & $\%$ & $n=40$ & $\%$ \\
\hline \multicolumn{7}{|l|}{ Umur (Tahun) } \\
\hline $20-30$ & 18 & 90,0 & 15 & 75,0 & 33 & 82,5 \\
\hline $31-35$ & 2 & 10,0 & 5 & 25,0 & 7 & 17,5 \\
\hline \multicolumn{7}{|l|}{ Tingkat Pendidikan } \\
\hline Dasar (SD, SMP) & 3 & 15,0 & 4 & 20,0 & 7 & 17,5 \\
\hline Menengah (SMU) & 14 & 70,0 & 12 & 60,0 & 26 & 65,0 \\
\hline Tinggi (Serjana) & 3 & 15,0 & 4 & 20,0 & 7 & 17,5 \\
\hline \multicolumn{7}{|l|}{ Pekerjaan } \\
\hline Bekerja & 4 & 20,0 & 6 & 30,0 & 10 & 25,0 \\
\hline Tidak Bekerja & 16 & 80,0 & 14 & 70,0 & 30 & 75,0 \\
\hline \multicolumn{7}{|l|}{ Paritas } \\
\hline Primigravida & 11 & 55,0 & 5 & 25,0 & 16 & 40,0 \\
\hline Multigravida & 9 & 45,0 & 15 & 75,0 & 24 & 60,0 \\
\hline
\end{tabular}

Berdasarkan Tabel 1. Pada karakteristik responden kelompok perlakuan umur yang paling banyak yaitu di umur 20-30 tahun yaitu 18 orang (90\%), demikian juga pada responden di kelompok kontrol yang paling banyak responden umur 20-30 yaitu sebanyak 15 orang (75\%). Sedangkan pada tingkat pendidikan untuk kelompok perlakuan dan kelompok kontrol jumlah responden terbanyak iyalah di pendidikan menengah sejumlah 14 orang $(70 \%)$ kelompok perlakauan dan 12 Orang $(60 \%)$ pada 
kelompok kontrol, untuk karakteristi responden berdasarkan pekerjaan sebagian besar pada kelompok perlakuan maupun kelompok kontrol iyalah ibu yang tidak bekerja yaitu 16 orang $(80 \%)$ kelompok perlakuan dan 14 orang $(70 \%)$ pada kelompok kontrol. Sedangkan Paritas pada responden perlakuan dalam penelitian ini lebih dominan ibu dengan paritas primipara yaitu sebanyak 11 orang $(55 \%)$, sedangkan untuk kelompok kontrol lebih banyak pada paritas ibu multipara yaitu sebanyak 15 orang $(75 \%)$.

Tabel 2 Distribusi Hasil Pre dan Post Tingkat Nyeri lbu Bersalin pada Kelompok Perlakuan.

\begin{tabular}{clcccccc}
\hline & & \multicolumn{3}{c}{ Perlakuan } & \multicolumn{2}{c}{ Total } \\
\cline { 3 - 6 } Skor & Tingkat Nyeri (FPRS) & \multicolumn{2}{c}{ Pre } & \multicolumn{2}{c}{ Post } & n=40 & \% \\
\cline { 3 - 6 } & & $\mathbf{n = 2 0}$ & $\mathbf{\%}$ & $\mathbf{n = 2 0}$ & $\mathbf{\%}$ & & 0 \\
\hline 0 & Tidak Sakit & 0 & 0 & 0 & 0 & 0 & 0 \\
2 & Sedikit Sakit & 0 & 0 & 0 & 0 & 0 & 40 \\
4 & Agak Menggangu & 4 & 20 & 12 & 60 & 16 & 42,5 \\
6 & Menggangu Aktivitas & 9 & 45 & 8 & 40 & 17 & 17,5 \\
8 & Sangat Menggangu & 7 & 35 & 0 & 0 & 7 & 0 \\
10 & Tidak Tertahankan & 0 & 0 & 0 & 0 & 0 & 0 \\
\hline
\end{tabular}

Keterangan: Pre= Sebelum; Post $=$ Sesudah

Berdasarkan Tabel 2. Menunjukan bahwa pada awal penilaian (pre-test) sebelum penggunaan birthing ball sebagian besar responden mengalami tingkat nyeri yang mengganggu aktivitas dan sangat mengganggu yaitu sebanyak 9 orang $(45 \%)$ dan 7 orang $(35 \%)$, Tingkat nyeri ini mengalami perubahan atau penurunan jumlah setelah penilaian (post-test) sesudah penggunaan birthing ball yaitu menjadi 8 orang $(40 \%)$. Dan pada responden yang mengalami tingkat nyeri sangat menggangu juga mengalami perubahan dari 7 orang (35\%) setalah dilakukan birthing ball terjadi penurunan tingkat nyeri sehingga tidak ada lagi responden mengalami tingkat nyeri yang sangat menggangu.

Tabel 3. Distribusi Hasil Pre Dan Post Tingkat Nyeri Pada Responden Kontrol

\begin{tabular}{clcccccc}
\hline Skor & Tingkat Nyeri (FPRS) & \multicolumn{2}{c}{ Pre } & \multicolumn{2}{c}{ Post } & \multicolumn{2}{c}{ Total } \\
\cline { 3 - 7 } & & $\mathbf{n = 2 0}$ & $\mathbf{\%}$ & $\mathbf{n = 2 0}$ & $\mathbf{\%}$ & $\mathbf{n = 4 0}$ & $\mathbf{4}$ \\
\hline 0 & Tidak Sakit & 0 & 0 & 0 & 0 & 0 & 0 \\
2 & Sedikit Sakit & 0 & 0 & 0 & 0 & 0 & 0 \\
4 & Agak Menggangu & 9 & 45 & 6 & 30 & 15 & 37,5 \\
6 & Mengganggu Aktivitas & 11 & 55 & 11 & 55 & 22 & 55 \\
8 & Sangat Menggangu & 0 & 0 & 0 & 50 & 0 & 0 \\
10 & Tidak Tertahankan & 0 & 0 & 3 & 15 & 3 & 7,5 \\
\hline
\end{tabular}

Keterangan: Pre= Sebelum; Post $=$ Sesudah

Berdasarkan tabel 3 menunjukan bahwa pada awal penilaian tingkat nyeri (pretest) pada responden kontrol atau responden yang tidak mendapatkan perlakuan, sebagian besar responden merasakan nyeri mengganggu yaitu sebanyak 11 orang $(55 \%)$, dan mengganggu aktivitas yaitu sebanyak 9 orang ( $45 \%)$. Pada table ini terlihat tingkat nyeri mengalami peningkatan dimana pada akhir penilaian (post-test) responden yang mengalami nyeri yang tida tertahankan bertambah sebanyak 3 orang $(7,5 \%)$. Dan responden yang mengalami tingkat nyeri yang mengganggu aktivitas juga masih tetap 11 orang $(55 \%)$. 
Tabel 4. Hasil Uji Test Normalitas Tingkat Nyeri Pada Ibu Bersalin

\begin{tabular}{llccc}
\hline \multirow{2}{*}{ Tingkat Nyeri } & \multicolumn{3}{c}{ Spahiro-Wilk } \\
\cline { 3 - 5 } & & Statistic & df & Sig. \\
\hline Pre test & Perlakuan & 0,809 & 20 & 0,001 \\
Post test & Kontrol & 0,637 & 20 & $<0,001$ \\
& Perlakuan & 0,626 & 20 & $<0,001$ \\
& Kontrol & 0.745 & 20 & $<0,001$
\end{tabular}

${ }^{a}$ Lilliefors Significance Correction

Tabel 4 menunjukan bahwa nilai signifikan pada awal penilaian penelitian (pretest) didapatkan nilai $p$ yang kurang dari 0,05 yaitu 0,001 untuk kelompok yang diberikan perlakaun dan nilai $p$ sebasar $<0,001$ untuk kelompok kontrol. Begitupun pada akhir penilaian penelitian (post-test) diperoleh nilai signifikan kurang dari 0,05 untuk kelompok perlakuan dan kelompok kontrol yaitu $<0,001$. Artinya kelompok perlakuan dan kontrol pada awal dan akhir penilaian penelitian memiliki sebaran data yang tidak normal. Hal ini menunjukan bahwa analisis yang digunakan adalah analisis non parametric karna sebaran data tidak berdistribusi normal.

Tabel 5. Perbandingan Rerata Tingkat Nyeri Pra dan Post Pada Ibu Bersalin di Kelompok Perlakuan dan Kelompok Kontrol

\begin{tabular}{|c|c|c|c|c|}
\hline \multirow[t]{2}{*}{ _Kelompok } & \multicolumn{2}{|c|}{ Skor Nyeri } & \multirow[t]{2}{*}{$\Delta$} & \multirow[t]{2}{*}{ Sig } \\
\hline & $\begin{array}{c}\text { Pre-test } \\
\text { (mean } \pm S D)\end{array}$ & $\begin{array}{c}\text { Post-test } \\
\text { (mean } \pm S D)\end{array}$ & & \\
\hline Kontrol & $5,10 \pm 1,021$ & $6,00 \pm 1,947$ & 0,9 & 0,083 \\
\hline Perlakuan & $6,30 \pm 1,490$ & $4,80 \pm 1,005$ & 1,5 & $<0,001$ \\
\hline $\begin{array}{ll}\text { Seterangan: } \\
\text { Sig } & =\text { Wilc } \\
\text { SD } & =\text { Stan } \\
& =\text { Selis }\end{array}$ & $\begin{array}{l}\text { ned Ranks Tes } \\
\text { asi } \\
\text { t nyeri setelah }\end{array}$ & guan (post & & \\
\hline
\end{tabular}

Tabel 5 dalam penelitian ini menunjukan nilai rata-rata (mean) skor nyeri Pretes dan post-test pada kelompok perlakuan dan kelompok kontrol. Pada hasil nilai mean terdapat perubahan dari pre-test dan post-test yaitu selisih nilai rata-rata tingkat nyeri pada respoden kelompok perlakuan sebesar 1,5 dan responden kelompok kontrol 0,9. Dilihat dari selisih perubahan, berdasarkan rata-rata responden kontrol mengalami peningkatan skor nyeri. Sedangkan responden pada kelompok perlakuan mengalami perubahan selisih skor tingkat nyeri yang menurun. Dengan demikian dapat diartikan berdasarkan nilai mean bahwa pada responden perlakuan mengalami penurunan skor tingkat nyeri. Sedangkan dari hasil analisis dengan menggunakan Wilcoxon Signed Ranks Test dapat pula dilihat bahwa nilai Asymp. Sig. (2-tailed) kelompok kontrol 0,083 dan nilai Asymp. Sig. (2-tailed) responden yang mendapat perlakuan adalah $<0.001$. Sehingga nilai Sig responden kelompok perlakuan $<0.001<$ nilai $\alpha=0,05$ yang artinya Ha diterima. Dapat disimpulkan bahwa ada pengaruh penggunaan birthing ball terhadap penurunan skor nyeri pada Ibu bersalin kala I fase aktif di Puskesmas Lompoe. 


\section{PEMBAHASAN}

Berdasarkan hasil analisis bivariat menunjukan bahwa nilai Asymp. Sig. (2tailed) adalah $<0,001$. Sehingga nilai Sig<0,001 $<$ nilai $\alpha=0,05$ yang artinya $\mathrm{Ha}$ diterima. Dapat disimpulkan bahwa ada pengaruh penggunaan birthing ball terhadap penurunan tingkat nyeri pada lbu bersalin kala I fase aktif di Puskesmas Lompoe. Berdasarkan tabel tingkat nyeri ibu bersalin pada kelompok perlakuan menunjukan bahwa tingkat nyeri sebelum penggunaan birthing ball sebagian responden mengalami nyeri yang sangat mengganggu aktifitas yaitu sebanyak 7 orang $(35 \%)$, dan sesudah penggunaan birthing ball tingkat nyeri yang dirasakan mengalami perubahan sehinggat ibu bersalin tidak lagi merasa nyeri yang sangat mengganggu, dimana responden hanya merasakan nyeri yang mengganggu bukan nyeri yang sangat mengganggu. Karena penggunaan birthing ball sebagian Latihan atau terapi birthball yang dilakukan ibu bersalin dengan cara duduk dengan santai dan bergoyang di atas bola, memeluk bola selama kontraksi memiliki manfaat membantu ibu dalam mengurangi rasa nyeri saat persalinan. Seorang ibu yang mampu melakukan relaksasi seirama kontraksi uterus berlangsung maka ibu tersebut akan rnerasakan kenyamanan selama proses persalinannya. ${ }^{6,7}$ Selain itu birthball sangat baik mendorong dengan kuat tenaga ibu yang diperlukan saat melahirkan, posisi postur tubuh yang tegak akan menyokong proses kelahiran serta membantu posisi janin berada di posisi optimal sehingga memudahkan melahirkan dengan normal. ${ }^{8-10}$ Selama terapi ibu bersalin duduk senyaman mungkin dan bentuk bola yang dapat rnenyesuaikan dengan bentuk tubuh ibu membuat ibu lebih mudah relaksasi, selain itu ligamen dan otot terutama yang ada di daerah panggul menjadi kendor dan mengurangi tekanan pada sendi sacroiliac, pembuluh darah sekitar uterus dan tekanan pada kandung kemih, punggung, pinggang, tulang ekor serta dapat mengurangi tekanan pada perineum. ${ }^{11,12}$

Hal ini sejalan dengan yang dilakukan oleh Kwan et al, yaitu penggunaan birth ball pada intrapartum memberi kontribusi dalam meningkatkan efikasi diri ibu selama persalinan dan mengurangi rasa sakit. Sebanyak 66\% melaporkan penurunan tingkat nyeri setelah menggunakan birth ball, $8 \%$ melaporkan nyeri yang lebih dari sebelumnya, $26 \%$ melaporkan tidak ada perubahan dalam tingkat nyerinya. ${ }^{13}$

Berdasarkan hasil penelitian Maryani, 2016 di Yogyakarta diketahui responden dari kelompok perlakuan cenderung mengalami intensitas penurunan nyeri persalinan dibandingkan pada kelompok kontrol. Hasil uji Chi square diperoleh niiai $X=7.925$ dengan nilai signifikansi yang artinya ada hubungan yang signifikan antara terapi birthball dengan penurunan intensitas nyeri persalinan. ${ }^{14}$

Dengan demikian peneliti berpendapat nyeri yang dirasakan saat persalinan merupakan hal yang fisiologis karena adanya kontraksi. Nyeri yang dirasakan setiap ibu berbeda-beda (bersifat subjektif) sesuai dengan faktor eksternal dan internal yang dimiliki. ${ }^{11}$ Banyak usaha atau metode yang dapat diterapkan untuk mengatasi rasa nyeri saat persalinan salah satunya dengan menggunakan birthing ball. ${ }^{13,15}$ Selain dapat menurunkan nyeri saat pembukaan pada kala I, birthing ball memiliki manfaat lain diantaranya dapat mengurangi angka kejadian kala I memanjang, mempercepat pembukaan serviks, merangsang kontraksi uterus, memperlebar diameter panggul serta mempercepat penurunan kepala janin, dengan ini penggunaan birthing ball sangat disarankan untuk ibu hamil, bersalin dan nifas. ${ }^{14}$ 


\section{SIMPULAN DAN SARAN}

Berdasarkan hasil penelitian dapat disimpulkan bahwa terdapat Pengarauh Birthing Ball terhadap penguranga nyeri persalinan pada kala I fase aktif. Saran yang diberikan untuk para praktisi bidan adalah terkhusus yang bertugas di kamar bersalin yaitu Penggunaan birthing ball ini dapat diterapkan sebagai salah satu upaya untuk meningkatkan pelayanan kesehatan dan untuk mengurangi angka kesakitan ibu saat persalinan latihan fisik berupa latihan birth ball sebaiknya dilakukan sejak kehamilan trimester 3 yang dapat diselenggarakan secara terintegrasi dalam kelas ibu hamil, serta tersedianya fasilitas latihan fisik bagi ibu hamil dan bersalin di tempat pelayanan persalinan. Untuk ibu bersalin penggunaan birthing ball ini dapat digunakan sebagai salah satu cara mengurangi angka kesakitan secara nonfarmakologi bagi ibu saat persalinan. Peneliti selanjutnya diharapkan dapat mengkaji lebih banyak sumber dan referensi yang terkait dengan manfaat birthing ball pada ibu hamil dan bersalin agar hasil penelitianya lebih baik dan lebih lengkap lagi.

\section{UCAPAN TERIMA KASIH}

Penulis menyampaikan terimakasih kepada Dirjen DIKTI yang telah membiayai penelitian mengenai Birthing Ball sehingga penelitian ini dapat berjalan dengan baik, selain itu penulis juga menyampaikan terima kasih kepada ketua LPPM STIKES Mega Buana yang telah memberikan informasi dalam proses penelitian sehingga penelitian ini dapat berjalan dengan lancara dan selesi tepat waktu. Serta terima kasih kepada pimpinan Puskesmas Lompoe dan bidan yang dinas di kamar bersalin, sebagai tempat penelitian, atas bantuan tenaga dan fasilitas yang telah diberikan.

\section{DAFTAR PUSTAKA}

1. Triana. Pengaruh Penggunaan Birthing Ball Terhadap Penurunan Skor Nyeri Pada Ibu Bersalin Kala I Fase Aktif Di Klinik Bersalin. J Kebidanan Bekasi. 2019;5(1).

2. Badan Kependudukan dan Keluarga Berencana Nasional, Badan Pusat Statistik, Kementerian Ksehatan R.I., MEASURE DHS, ICF International. Survei Demografi dan Kesehatan Indonesia 2012. Jakarta: Badan Kependudukan dan Keluarga Berencana Nasional; 2013.

3. Nawir H. Angka Kematian Ibu dan Bayi di Parepare Tinggi, Ini Penyebabnya [Internet]. news.rakyatku.com. 2016 [cited 2019 Oct 23]. Available from: http://news.rakyatku.com/read/9738/2016/06/19/angka-kematian-ibu-dan-bayi-diparepare-tinggi-ini-penyebabnya

4. Bandiyah S. Kehamilan Persalinan \& Gangguan Kehamilan. Yogjakarta: Mitra Cendikia Press; 2009.

5. Nichols FH, Humenick SS. Childbirth Education: Practice, Research and Theory. Philadelphia: Saunders; 2000.

6. Putri SA, Khotimah S. Perbedaan Pemberian Senam Hamil dan Yoga Terhadap Peningkatan Durasi Tidur Ibu Hamil Trimester III [Internet]. [Yogyakarta]: Universitas 'Aisyiyah Yogyakarta; 2017 [cited 2019 Oct 23]. Available from: http://digilib.unisayogya.ac.id/2232/

7. Rusmita E. Pengaruh Senam Hamil Yoga Terhadap Kesiapan Ibu Hamil Menghadapi Persalinan Di RSIA Limijati Bandung. J Keperawatan BSI. 2015;3(2).

8. Rafika R. Efektifitas Prenatal Yoga terhadap Pengurangan Keluhan Fisik pada Ibu Hamil Trimester III. J Kesehat [Internet]. 2018 May 25;9(1):86. Available from: http://ejurnal.poltekkes-tjk.ac.id/index.php/JK/article/view/763

9. Ashari A, Pongsibidang GS, Mikhrunnisai A. Pengaruh Senam Prenatal Yoga terhadap 
Penurunan Kecemasan Ibu Hamil Trimester III. Media Kesehat Masy Indones [Internet]. 2019 Mar 17;15(1):55. Available from: http://journal.unhas.ac.id/index.php/mkmi/article/view/5554

10. Pont AV, Rosiyana NM, Pratiwi V, Enggar, Nurfatimah, Ramadhan K. The Effect of Prenatal Yoga in Reducing Pregnancy Complaints. Indian J Public Heal Res Dev [Internet]. 2019;10(8):1218. Available from: http://www.indianjournals.com/ijor .aspx?target=ijor:ijphrd\&volume=10\&issue=8\&article $=223$

11. Gau M-L, Chang C-Y, Tian S-H, Lin K-C. Effects of birth ball exercise on pain and selfefficacy during childbirth: A randomised controlled trial in Taiwan. Midwifery [Internet]. 2011 Dec;27(6):e293-300. Available from: https://linkinghub.elsevier.com/retrieve/pii/S0266613811000192

12. Leung RW, Li JF, Leung MK, Fung BK, Fung LC, Tai S, et al. Efficacy of birth ball exercises on labour pain management. Hong Kong Med J [Internet]. 2013 Jul 22; Available from: http://www.hkmj.org/abstracts/v19n5/393.htm

13. Kwan W, Kwan WS, Chan S-W. Evaluation of Birth Ball The Birth Ball Experience: Outcome Evaluation of the Intrapartum Use of Birth Ball. Vol. 11, Hong Kong J Gynaecol Obstet Midwifery. 2011.

14. Maryani T, Estiwidani D. Terapi Birth Ball Berpengaruh terhadap Lama Kala II Dan Intensitas Nyeri Persalinan pada Ibu Bersalin Primigravida di RB Kasih Ibu Yogyakarta. J Kesehat Ibu dan Anak. 2016;10(2):22-7.

15. Hau W-L, Tsang S-L, Kwan W, Siu-King L, Rn M, Lam K-Y. The Use of Birth Ball for Pain Management The Use of Birth Ball as a Method of Pain Management in Labour. Vol. 12, Hong Kong J Gynaecol Obstet Midwifery. 2012. 